\title{
Sharia housing and millennials in Indonesia: Between religious and economic motives
}

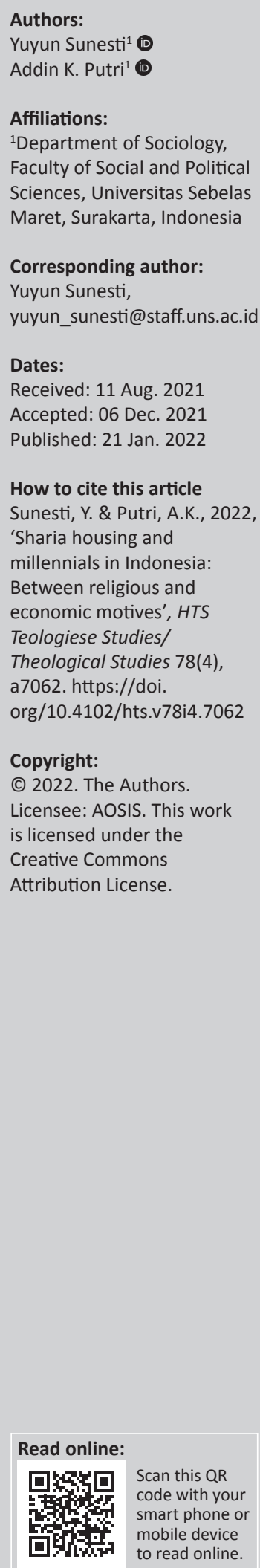

This article aims to discover why young people in Indonesia choose Islamic faith-based (sharia) housing that is more homogeneous than conventional housing. This is important because the growth of sharia housing in Indonesia has experienced a significant increase in the last five years. Sharia housing requires residents to be of the same religion, comply with the rules of purchase and follow the payment scheme according to Islamic law. In fact, in the last two years, this homogeneous housing has seen increasing demand among Muslim youth in Indonesia. Through in-depth interviews with 10 sharia housing buyers, this study explores the reasons behind young peoples' preference for sharia housing, which are not monolithic, that is, they are not solely made for ideological reasons, but are often made for economic reasons. Exploration of the various reasons for millennials choosing sharia housing is essential to understand the tendency of young people to prefer such exclusive residential complexes.

Contribution: This study reveals young Muslims' motivations in Indonesia to choose religious identity-based housing. It aims to contribute to the actual debates on the dynamics of young Muslims in Indonesia and their current trends in consuming Islamic faith-based products.

Keywords: Sharia housing; millennial; religious motive; economic motive; rational choice; emotional choice.

\section{Introduction}

This article analyses the reasons why the millennial Muslim in Indonesia, anyone born between 1981 and 1996 (aged 25 to 40 in 2021) (Dimock 2019), have chosen the faith-based housing, also known as sharia housing. Even though it is labelled as sharia, the motives of the millennials in choosing the housing are not only based on merely the sharia aspect. This article shows another motive in choosing sharia housing among Indonesian Muslim millennials.

Religion-based housing, especially Islamic faith-based or sharia housing, has become increasingly popular in Indonesia in the last 10 years. In addition to implementing payment methods that must comply with religious rules, such as no usury (riba, Isl.) or interest, this housing also requires residents to have the same religious identity. In this case, identifying as Muslim is the main requirement for buying a property in this kind of housing development. In the capital, Jakarta, for example, as of mid-2019, there were 83 Islamic housing clusters (Perumahan Islami Indonesia 2019). In the city of Solo in Central Java, where this research was conducted, as of June 2020, 35 Islamic housing estates were built.

There have been numerous studies on Islamic faith-based housing. However, the majority of these studies focus on sharia housing from the perspectives of economics, industry and marketing strategies (Firmansyah \& Indika 2017; Majid et al. 2018; Nadzifah \& Fataron 2019; Qorni \& Juliana 2020; Rahadi et al. 2021; Santoso, Saiban \& Munir 2021; Sylvana, Awaluddin \& Mutahajjid 2020), Islamic law (Asni \& Sulong 2018; Khoirrani \& Arifah 2021), architecture (Perdana 2020) and media (Muali \& Nisa 2019; Putri \& Sunesti 2021).

Studies that directly link millennials and Islamic housing are still limited. The majority of studies on millennials still focus on the relationship between millennials and sharia products in general, whereas this article focuses more specifically on millennials and sharia housing. More specifically, research has examined millennial interest in sharia products, especially Islamic banks (Bakry, Masse \& Arake 2021; Syafrida, Aminah \& Awaludin 2020), halal tourism (Supaijo \& Fermansyah 2019), Islamic insurance (Belianti, Alim \& Awaliyah 2019) and the linkage of millennial Islamic economic literacy with the choice of sharia products (Wijayanti \& Hidayat 2020). Another study 
looks at the contribution of the millennial generation to the Islamic economic movement through mastering technology to disseminate information about Islamic economics to a broader audience (Nurhidayat 2020).

Several other studies have tried to analyse the relationship between religiosity and the choice of sharia products (Wijayanti \& Hidayat 2020). Wijayanti and Hidayat (2020) found that the variables of religiosity and promotion had a positive effect on millennial interest in using ownership credit products in Islamic banks. The increase in religious awareness, recently known as the hijrah (migration, Ar.) movement, is believed to bear influence on the preferences of the millennial generation for sharia property. However, is the increased awareness of religious symbols also in line with millennials' preference for sharia housing?

It is essential to study the relationship between Islamic housing and the choices of young people not only because of the large number of this group but also because millennials represent a high percentage of those looking for a place to live. According to the Indonesian Central Statistics Agency (Badan Pusat Statistik [BPS]) census, from February to September 2020, millennials totalled 69.9 million people or $25.87 \%$ of the population. Millennials represent a high percentage of the group looking for a place to live according to the Indonesian Real Estate survey in 2020, and they represent $72 \%$ of sharia mortgage loan (kredit pemilikan rumah [KPR]) enthusiasts (Kompas.id 2020; REI 2020).

Young people are also important objects of study because their religious tendencies are unstable, and they are often changeable and may experience identity crisis because of social changes that occur around them (Hasan 2006; Sunesti, Hasan \& Azca 2018). Young people also provide more diverse responses in facing and overcoming the uncertainties in their lives (Hasan 2006). This research aims to reveal the extent to which Indonesian Muslim youth are interested in sharia housing, where life tends to be more homogeneous than housing in general. Through this study, the reasons for choosing sharia housing will be revealed: whether it is purely ideological, economic or for other reasons.

\section{Research method and design}

This research is qualitative in approach and aims to reveal young people's reasons for buying into sharia housing. As Marvasti (2004:7) states, 'qualitative research provides a detailed description and analysis of the quality, or the substance, of the human experience'. This study aims to reveal the experiences of buyers of sharia housing, including their reasons for and impressions of buying this housing.

Data were collected from June to November 2020 through in-depth interviews among 10 young people, aged between 25 and 40 years, who bought sharia housing in Solo Raya. Solo Raya is a term to designate several areas included in the Surakarta ex-residency with geographical and cultural proximity to Surakarta. These areas include Surakarta,
Sragen, Sukoharjo, Karanganyar, Boyolali and Wonogiri. This research chose Solo Raya because this area is considered the centre of the emergence of fundamentalist Islamic movements and groups in Java (Wildan 2008). On the other hand, the city is also known as the centre of local Javanese culture. The focus of the study on this city is relevant to see how interested young people in Solo Raya are in the trend of Muslim housing, which is currently increasing generally.

\section{Results \\ Religion based-housing: Islamic case}

Housing is defined in various ways by scholars; however, Melnikas's (1998) definition of the term provides a general idea, according to which housing is defined as:

[A] specific and relatively limited, physically, biologically socially close place where people and groups of people can live their biosocial life, by receiving services, performing house chores and other biosocial activity. (p. 326)

In a similar definition, Law of the Republic of Indonesia Number 1 Year 2011 concerning Housing and Residential Areas stated that housing is defined as:

$[A]$ collection of houses as part of a settlement, both urban and rural, which are equipped with infrastructure, facilities and public utilities as a result of efforts to fulfill a livable house. (p. 3)

In their definition of housing, Bowers and Manzi (2006) highlighted that, in general, housing is exclusive because of the fences that surround it. The definition used here is one in which housing can be generally understood as a group of houses, generally fenced so that they are usually exclusive, equipped with shared facilities and inhabited by a group of people who carry out joint social activities at times - a perumahan.

In Indonesia, religious-based housing, predominantly Muslim housing, was recorded for the first time as a property business enterprise around the 1990s in big cities such as Jakarta (Lasman 2007). This type of housing development was believed to be a form of expression and articulation of Islamic identity, which began to develop at that time along with the increasing awareness of Islamic culture and politics, which was influenced by the political shift of Suharto's New Order regime (1966-1998) towards Islam (Effendi 2003). However, a significant growth in Muslim housing began to be seen around the 2000s after the fall of the New Order regime, when Islamisation was increasingly built and strengthened among middle-class Muslims (Liddle 1996:72-74).

Although no literature specifically explains when Muslim housing in post-New Order Indonesia began to grow noticeably, the number of Muslim housing estates built to date shows a significant increase. Data from Indonesian Muslim housing sites show that until mid-2019, in the Indonesian capital, Jakarta, and its surroundings, there were 
83 sharia housing areas built (Perumahan Islam Indonesia 2019). Meanwhile, in Solo Raya, about 35 sharia housing areas were built before June 2020 .

According to Helen and Gamal (2017), Muslim housing, better known as sharia housing, has three aspects: property design, property development and financial transactions. The implementation of these three aspects is based on the Islamic principle. On the other hand, Arifin (2017:86) stressed that the definition of Muslim housing is not yet clear. From the results of his research in Yogyakarta, he found three signs about Muslim housing, namely, the Muslim label attached to the housing, the occupants were Muslims and there is a mosque inside.

From interviews with developers and buyers of sharia housing in our research in Solo Raya, our study concludes that there are two concepts where housing is referred to as sharia housing. The first is sharia or Islamic in the transaction process and the second is Islamic in the environment inside the housing area. The first concept, sharia transactions, is characterised by the absence of usury (interest) in the selling value. Developers and buyers believe that usury is forbidden in Islam, so usually these buyers and developers of Islamic housing avoid using banks in the transaction process. Sharia transactions are also manifested in an initial agreement between buyer and developer on the payment method, the amount of the down payment and the number of instalments if the buyers prefer to pay in instalments. Furthermore, no penalty fee is applied to the buyer if the buyer cannot pay on time. Buyers are only asked to notify the developer if they cannot pay at the agreed time, along with the underlying reasons. Not using insurance is also a requirement in sharia transactions because they believe the use of insurance will keep them from believing and depending on God's provisions.

The second concept of sharia housing is an Islamic environment. This Islamic environment consists of two elements, namely, Islamic facilities and Islamic activities. Islamic facilities include a mosque, tahfidz [reciting Quran] house, sunnah [habitual practice according to the tradition of the Prophet] and sporting facilities, namely, for archery and swimming. The Islamic activities residents usually engage in together include praying in congregation at the mosque at designated times, wearing the hijab for women, separate areas for men and women if there is a joint event and regular Quran recitations for men, women and children.

\section{Millennials and multiple motives}

Choosing to live in a community that tends to be exclusive such as in sharia housing is gaining popularity today. The massive development of sharia housing in Indonesia is an indicator of increased preference of consumers for this type of housing. Khadijah (45 years old), a female developer of Sharia Housing and one of the informants in this study, said that, on average, millennial buyers make up $60 \%$ of total sales of sharia housing every year in her property sale. The increasing number of millennials who choose this type of housing raises the question of why these young people choose this type of residence.

One of the participants in this study, Heni (25 years old), chose to buy a new sharia housing complex built by a developer after two years of marriage. Wanting to be independent and no longer live with parents was the main reason for the couple looking for their own home. However, they have their reasons for choosing sharia housing over other conventional housing. According to Heni, sharia housing provides several advantages compared with other housing. The first advantage is that sharia housing requires payments without usury, namely, cash payments or instalments, without applying an additional purchase value. Heni admits that this payment method is financially profitable and it follows the demands of sharia law that she believes in. In addition, buying sharia housing is not burdened by a down payment because the down payment and the instalments are determined according to the agreement between the buyer and the housing developer. The absence of fines for late payments is another reason why Heni preferred this form of housing.

Furthermore, being usury-free and with good payment conditions, Heni also chose to buy sharia housing because of the environment she will live in. According to Heni, sharia housing, where all residents are Muslim, is more comfortable because it will be more suitable for the development of their children in the future than an environment with residents who have different religious backgrounds. She believed that with Muslim co-residents in the estate, it will be easier for her family to maintain their faith and daily activities.

A similar reason for buying sharia housing was also expressed by Ghofar (30 years old). Since studying religion in recent years, Ghofar wants all aspects of his life to be as close as possible to religious rules, including choosing a place to live. The first reason for choosing sharia housing for his future residence is because the payment model does not contain the element of usury, which he believes is sinful in Islam. Ghofar admitted that he was interested in one of the sharia housing areas on the outskirts of the city of Solo because it provided complete facilities for worship. The housing offers mosque facilities, tahfidz houses, swimming pools and archery fields. Some Muslims believe swimming and archery are sports that follow the sunnah (customs) of the Prophet Muhammad, so these sports are highly recommended as sports of choice for Muslims. Indeed, some Muslim housing developments offer these sporting facilities to attract buyers.

Another participant, Irfan (28 years old), acknowledged that tolerance between religions is an important thing to introduce to his children, and he still prefers sharia housing as his place to live in the future. He reasoned that by living in an environment in which people have the same religious 
identity, it is easier for him to synchronise the style of education for his children with that practiced in the community where he lives. Irfan feels that if the style of Islamic education he applies to his children is different from the environment in which they live, it will be tough for him to educate his children the way he wants.

While Heni, Ghofar and Irfan have similar reasons for choosing sharia housing, Yeni (40 years old) and Sari (35 years old) reveal slightly different reasons. Although Yeni admits that she is interested in buying sharia housing because of the non-usury financing and the upfront agreement on payment between the buyer and developer, which she thinks is fair for both buyer and seller, she said she did not choose the housing because of religious reason. Yeni observed that buying the housing was for investment purposes and that she intended to rent out the property. Renting out the property has good prospects because of growing market demand for sharia housing and the increasing awareness of Muslims towards religious matters.

In line with Yeni, Sari, who works not far from the sharia housing she bought, also admitted that she purchased the housing for investment purposes. Although she did not know whether she would rent it out or occupy it herself, Sari admitted that it was not merely ideological reasons that prompted her to buy the housing. The strategic position of the housing, close to a well-known campus in Solo, is Yeni's main consideration for buying it.

\section{Sharia housing and millennials' ideological motive}

The reasons put forward by the informants who were sharia housing buyers are divided into two tendencies. The first tendency is related to ideological preferences: buyers who buy housing based on their beliefs to follow the Islamic teachings. The second trend is that young people buy sharia housing for economic reasons, namely, as an investment for the future.

Young people who state ideological reasons as the main reason for buying sharia housing think that sharia housing is the right place to live in because it offers payment methods and an Islamic environment that suits their beliefs. For these people, these two things are important because they contribute to the preservation of their faith. Mosque facilities in the housing will make it easier for them to go to a familiar mosque. The tahfidz house available will also encourage them to participate in reading and memorising the Qur'an regularly not only for them but also for their children. In addition, archery and swimming sports facilities will also teach their children about the Prophet's sports habits, which if they follow will bring rewards and strengthen their faith.

Several scholars explain the phenomenon of exclusive communities living in one settlement with diverse backgrounds as gate communities or enclave societies. Turner (2007:290) described the enclave society as 'a society, governments and other agencies seek to regulate spaces and where necessary to immobilise flows of people, goods and services'. In the case of sharia housing, a group of people who have the same identity, the same life goals and the same ideology build a particular space to live in, adhere to the same rules and share similar life goals. In this context, these housing estates provide facilities to support their everyday life, so in some ways, they encourage immobility among this group. In the same vein, Hasan (2006) saw this enclave as a call to return to a fundamental identity by establishing boundaries with the world outside them, which they perceive as different from them.

The community of people in this housing establish boundaries within the housing community and in relation to the wider community beyond the housing estate. The existence of a gated system that was built for security reasons limits the interactions of people both inside and outside the housing estate. According to the sociological concept, gated communities are (Blakely \& Snyder 1997):

$[R]$ esidential areas with restricted access in which normally public spaces are privatized. They are security developments with designated perimeters, usually walls or fences, and controlled entrances that are intended to prevent penetration by non-residents. (p. 2)

In the case of sharia housing, these houses are built on the concept of a one gate system to the housing designed to provide safety for residents. However, unlike the usual fenced housing, which functions to ensure physical security, ideologically, this fence symbolises protection against ideological threats that are in conflict with those of its residents. In this fenced community, the residents protect their security from outside criminal acts and from the influence of other ideologies that will threaten their beliefs and identity. In fact, Arifin (2019) further saw that the ideology of preservation in the sharia housing has also been developed by developers and puritan Islamic groups.

Most of the millennials in this study tended to build their lives and identities, in part, through their sharia housing selection. They dream of their future life, one in which their children will be saved by their religious and ideological identity through living in this type of housing. As most sharia housing offers an exclusive environment to ensure the preservation of the community's ideology such as the choice to live with only Muslims and reject non-Muslim inhabitants, there is the likelihood that exclusive attitudes may develop among young people who choose sharia housing.

\section{Sharia housing and the millennial business investment}

As we have seen, some young people choose sharia housing for emotional or ideological reasons, and some for economic reasons, namely, to invest in the future. In this case, many people admitted that sharia housing was a rational choice for several reasons, such as a relatively uncomplicated payment method according to the agreement and no fines for late 
payments. The location of the housing estates, some of which are quite strategic, makes the purchase of this type of housing a sound business investment for owners wishing to rent out properties.

As Khodijah, a female developer, stated that $60 \%$ of her sharia property buyers are people between 25 and 40 years of age, millennials are the target market for the business industry, including sharia properties. Therefore, although sharia housing is dominantly chosen by young people for ideological reasons, those who are with non-ideological reasons can also be found. These young people usually buy not because they want to live in, but because they see the economic potential that can be generated from the development of Islamic housing trends lately.

Fealy (2007) and Hasan (2009) found the potential for consumption of religious products shortly in the postreformation era in Indonesia when Islamisation began to grow and develop among middle-class Muslims. Fealy (2007) called this phenomenon commodified Islam marked by the emergence of the Islamic economy or the provision of a service or a product identified with Islam not only in financial services but also in predication and education. This phenomenon is then captured by Muslims by consuming these Islamic products as a form of expression of piety on the one hand and economic opportunities on the other hand.

In addition, in products labelled with Islamic sharia, millennials have increased as consumers. The ease of interest in religion-labelled products can be understood, as Hasyim (2018) said, that basically Indonesian millennial Muslims preserve and have a deep commitment to their Islamic doctrines. Their commitment to religious doctrine makes it likely easier for millennials to choose those products. However, the characteristics of millennials mentioned by Hasan (2006) are as follows: they are unstable in religion, labile and may experience an identity crisis that compels millennials to have other strategies to deal with their conditions and future. Therefore, on the one hand, the ideological belief to live comfortably in the same community in the sharia housing is an option. On the other hand, economic survival through business investment is also another option. Investment is a rational choice for millennials because they see the increasing opportunities for sharia housing enthusiasts. For this reason, several informants stated that they bought sharia housing to be rented back and not occupied by them. From these findings, it can be highlighted that the increasing consumption of products labelled with religion does not always indicate an increase in the religious awareness of young people in Indonesia. Although ideological motive has still dominated among millennial Muslims, the fact that millennials have different motives shows the dynamics of young Indonesian Muslims in negotiating their emotional and rational choices.

\section{Conclusion}

The increase in religious activities and the choice of religious symbols for millennial youth is indeed increasing lately. Evidence shows that religious activities both offline and online are very popular with young people. This affects the choices of Muslim youth in housing that represents an increase in their religious activities. Although several surveys have confirmed this trend, this study found various reasons as to why young people choose Islamic housing. These reasons are not purely ideological, but include rational reasons, such as for investment purposes and future economic security.These reasons illustrate the extent to which Muslim youth in Indonesia are attracted to choose products with religious labels, why they choose these products and what they want to build with these choices. Although the choice of young people in buying sharia housing is not monolithic, ideological motives remain the dominant reason. In addition, as my study focused on a limited number of informants and was conducted in Solo Raya, the article's findings could be different when it applies to more numbers of informants or in other areas of Indonesia. Despite this limitation, this study complements the discussion on the dynamics of Muslim millennials in Indonesia, which specifically portrays the relationship with the issue of sharia housing, which is currently developing.

\section{Acknowledgements}

The authors would like to thank Universitas Sebelas Maret for all facilities provided to support this research.

\section{Competing interests}

The authors declare that they have no financial or personal relationships that may have inappropriately influenced them in writing this article.

\section{Authors' contributions}

Y.S. conceived of the presented idea, developed the theory, writing and editing and verified the analytical methods. A.D.K. contributed to the design and implementation of the research. Both authors discussed the results and contributed to the final manuscript.

\section{Ethical considerations}

This article followed all ethical standards for research without direct contact with human or animal subjects.

\section{Funding information}

This research received a grant from PNBP Universitas Sebelas Maret Surakarta.

\section{Data availability}

Data sharing is not applicable to this article as no new data were created or analysed in this study. 


\section{Disclaimer}

The views and opinions expressed in this article are those of the authors and do not necessarily reflect the official policy or position of any affiliated agency of the authors.

\section{References}

Arifin, K.A., 2017, 'Perumahan Muslim dan politik ruang di Yogyakarta', Jurna Pemikiran Sosiologi 4(1), 42-56. https://doi.org/10.22146/jps.v4i1.23627

Arifin, K.A., 2019, Politik Ruang Perumahan Muslim, Lintas Nalar, Yogyakarta.

Asni, F. \& Sulong, J., 2018, 'Syariah analysis on hybrid contracts and its applications in Islamic housing financing in Malaysia', The Turkish Online Journal of Design, Art and Communication, September(Special Edition), 1457-1462.

Bakry, M., Masse, R.A. \& Arake, L., 2021, 'How to attract millennials? Indonesian sharia banking opportunities', Wseas Transactions on Business and Economics 18, 376-385. https://doi.org/10.37394/23207.2021.18.38

Belianti, L., Alim, F.A. \& Awaliyah, H., 2019, 'Millennial interests on Islamic insurance: The role of mobile service and satisfaction', AIJIEF: Airlangga International Journa of Islamic Economics and Finance 2(2), 123-143. https://doi.org/10.20473/aijief. v2i 2.20660

Blakely, E.J. \& Snyder, G.M., 1997, 'Divided we fall: Gated and walled communities in the United States', in N. Ellin (ed.), Architecture of fear, pp. 85-99, Princeton Architectural Press, New York, NY.

Bowers, B.S. \& Manzi, T., 2006, 'Private security and public space: New approaches to the theory and practice of gated communities', European Journal of Spatia Development 22, 1-17.

Dimock, M., 2019, 'Defining generations: Where Millennials end and Generation Z begins', Pew Research, 01 March, viewed 14 June 2021, from https://www. pewresearch.org/fact-tank/2019/01/17/where-millennials-end-and-generationz-begins/.

Effendi, B., 2003, Islam and the state in Indonesia, Institute of Southeast Asian Studies, Singapore.

Fealy, G., 2007, 'Consuming Islam: Commodified religion and aspirational pietism in contemporary Indonesia', in G. Fealy \& S. Dan White (eds.), Expressing Islam: Religious life and politic in Indonesia, pp. 15-39, ISEAS, Singapore.

Firmansyah, E.A. \& Indika, D.R., 2017, 'Kredit pemilikan rumah syariah tanpa bank: studi di Jawa Barat', Jurnal Manajemen Teori dan Terapan 10(3), 223-230. https:// doi.org/10.20473/jmtt.v10i3.6541

Hasan, N., 2006, Laskar Jihad: Islam, militancy, and the quest for identity in post-new order Indonesia, Cornell Southeast Asia Program, Ithaca, NY.

Hasan, N., 2009, 'The making of public Islam: Piety, agency, and commodification on the landscape of the Indonesian public sphere', Contemporary Islam 3, 229-250. https://doi.org/10.1007/s11562-009-0096-9

Hasyim, S., 2018, 'The millennial generation: Deciding Bloc?', (RSIS Commentaries, No. 147), RSIS Commentaries, Singapore, Nanyang Technological University, viewed 14 June 2021, from https://hdl.handle.net/10356/88814.

Helen, N. \& Gamal, A., 2017, 'Sharia housing in the real estate business', Internationa Conference on Construction and Real Estate Management, pp. 27-41, November 10-12, 2017, Guangzhou, China, viewed 09 June 2021, from https://ascelibrary. org/doi/abs/10.1061/9780784481073.004

Khoirrani, T.L. \& Arifah, R.N., 2021, 'Default solution on sharia housing in the view of private law and Islamic law', At-Turas: Jurnal Studi Keislaman 8(1), 27-48. https:// doi.org/10.33650/at-turas.v8i1.1603

Kompas.id, 2020, 'KPR syariah diminati generasi milenial', kompas.co.id, 29 September 2020, viewed 09 June 2021, from https://www.kompas.id/baca/lainlain/2020/09/29/kpr-syariah-diminati-generasi-milenial.
Lasman, D.K., 2007, Representasi identitas dalam brosur dan artikel perumahan Muslim, P.S Prancis Fakultas IImu Budaya Universitas Indonesia, viewed 05 June 2021, from http://staff.ui.ac.id/user/343/publications.

Liddle, R.W., 1996, 'The Islamic turn in Indonesia: A political explanation', Journal of Asian Studies 55(3), 72-74. https://doi.org/10.2307/2646448

Majid, R.N., Rahadi, R.A., Faturohman, T. \& Hasanah, E.N., 2018, 'Factors influencing sharia housing products pricing in Bandung city: A preliminary study', Journal of Islamic, Social, Economics and Development 3(8), 70-86.

Marvasti, A.B., 2004, Qualitative research in sociology, Sage, London.

Melnikas, B., 1998, 'Management and modernization of housing facilities: Specific features of Central and Eastern European Countries', Facilities 16(11), 326-333. https://doi.org/10.1108/02632779810233601

Muali, C. \& Nisa, K., 2019, 'Pemasaran syariah berbantuan media sosial: kontestasi strategis peningkatan daya jual', An-Nisbah: Jurnal Ekonomi Syariah 05(02), 168-185. https://doi.org/10.21274/an.2019.6.1.168-185

Nadzifah, M. \& Fataron, Z.A., 2019, 'Strategy analysis of building sharia residential property business without banks (A Case study of "Semarang Ngaliyan Residence" syariah housing in West Semarang)', Jurnal Ilmiah Ekonomi Islam 5(3), 265-276. https://doi.org/10.29040/jiei.v5i3.645

Nurhidayat, 2020, 'Muslim milenial dan gerakan ekonomi Islam Indonesia', Mizan: Journal of Islamic Law 4(1), 131-140. https://doi.org/10.32507/mizan.v4i1.638

Perdana, A., 2020, 'Evaluation of physical aspect of Islamic residential concept in the sharia housing project', Journal of Architecture and Environment 19(2), 149-172. sharia housing project', Journal of Architecture and
https://doi.org/10.12962/j2355262x.v19i2.a6898

Perumahan Islami Indonesia, 2019, Daftar perumahan Islami-perumahan syariah Indonesia, viewed 21 May 2021, from http://www.perumahanislamiindonesia. com/p/daftar-lokasi.html.

Putri, A.K. \& Sunesti, Y., 2021, 'Sharia branding in housing context: A study of hala lifestyle representation', Jurnal Sosiologi Walisongo 5(1), 77-92. https://doi. org/10.21580/jsw.2021.5.1.7268

Qorni, G.F.W.A. \& Juliana, J., 2020, 'Sharia property purchase decision without bank: Analysis of the influence of price factors, environment and religiosity', Jurnal Ekonomika dan Bisnis Islam 3(3), 234-245.

Rahadi, R.A., Majid, R.N., Faturohman, T., Hasanah, E.N. \& Rahmawati, D., 2021, 'Real estate developer perception for sharia housing products in greater Bandung,
Indonesia', Journal of Emerging Economies \& Islamic Research 9(1), 54-67. https://doi.org/10.24191/jeeir.v9i1.10615

REI, 2020, 'Milenial lebih minat KPR syariah', Real Estate Indonesia, rei.orid, 14 Oktober 2020, viewed 14 June 2021, from https://www.rei.or.id/newrei/beritamilenial-lebih-minat-kpr-syariah.html.

Santoso, B., Saiban, K. \& Munir, M., 2021, ‘Pemenuhan Maqasid al-Shariah dalam Perumahan Islami: Studi Pada Perumahan Islami De Prima Malang', El-Aswaq 2(2).

Sunesti, Y., Hasan, N. \& Azca, M.N., 2018, 'Young Salafi-niqabi and hijrah: Agency and identity negotiation', Indonesian Journal of Islam and Muslim Societies 8(2), 173-197. https://doi.org/10.18326/ijims.v8i2.173-197

Supaijo, S. \& Fermansyah, D., 2019, 'The perception of Muslim millennial travelers towards halal tourism', Journal of Islamic Business and Economic Review 2(1), 43-51.

Syafrida, I., Aminah, A. \& Awaludin, T., 2020, 'Keputusan penggunaan jasa perbankan syariah: perspektif nasabah milenial', Bisnis: Jurnal Bisnis dan Manajemen Islam 8(1), 49-66. https://doi.org/10.21043/bisnis.v8i1.6691

Sylvana, A., Awaluddin, M. \& Mutahajjid, A., 2020, 'Marketing strategy model based on the benefit of sharia property developers in Indonesia', Palarch's Journal of Archaeology of Egypt/Egyptology 17(7), 8123-8135.

Turner, B.S., 2007, 'The enclave society: Towards a sociology of immobility', European Journal of Social Theory 10(2), 287-303. https:/doi.org/10.1177/1368431007077807

Wijayanti, T.N. \& Hidayat, F., 2020, 'Minat generasi milenial terhadap produk pembiayaan KPR Bank Syariah', Equilibrium: Jurnal Pendidikan 8(2), 170-180. https://doi.org/10.26618/equilibrium.v8i2.3460

Wildan, M., 2008, 'Mapping radical Islamism in Solo: A study of proliferation of radical Islamism in Central Java Indonesia', Al-Jami'ah: Journal of Islamic Studies 46(1), 35-69. 